\title{
Some Legal Aspects of Abbreviated Trial in Albania
}

\author{
Naim Mëçalla \\ Jurgen Mëçalla \\ University College "Wisdom", Tiranë, Albania
}

\begin{abstract}
The Criminal Procedure Code of the Republic of Albania, as amended, came as an expression of the society's need for a more effective fight against criminality, a process that should go hand in hand with respect of the human rights and fundamental freedoms. This code, among other things, brought a new concept with regard to the possibility of applying special proceedings, as alternatives to the ordinary proceedings of investigation and judgment in the criminal cases. Thus, after nearly half a century, is reinstated in the Criminal Procedure Code, the special proceedings institute and for the first time in the history of the Albanian procedural law, an abbreviated trial, is foreseen as an alternative judgment. In this context, this paper gives an overview of the abbreviated trial, its legal meaning and the advantages it brings to the parties in particular and to the criminal process in general. The paper also contains a synthesized review of the abbreviated trial, under Albanian legislation and addresses some of the issues of judicial practice, as well as a brief presentation at a practical point of view of the abbreviated trialcases, answering some of the problems arising from the practice.
\end{abstract}

Keywords: The abbreviated trial, a regular legal process, criminality, the presumption of innocence.

\section{Introduction}

The abbreviated trial enters into the category of special proceedings, which is foreseen by articles 403-406 of the Criminal Procedure Code ${ }^{1}$. The court, when the defendant hasrequired to proceed with this kind of judgment, has to evaluate whether he can define the trial according to the acts. Thus, an abbreviated trial is not performed automatically at the request of the defendant, but also requires the approval of a judge who may refuse the request if he thinks that an ordinary trial is necessary. The abbreviated trialis of value to the judicial economy because it simplifies and shortens the procedures, increases the speed and effectiveness of the judgment and brings a benefit to the defendant, reducing the one-third of the sentence and not applying the life imprisonment sentence. This benefit should in no way undermine the righteous process.

So the defendant's and his legal representative request is accepted by the court only when it practically creates the inner conviction thatthe case can be resolved without the need for judicial review. Not unintentionally, Article 403/2 of the Criminal Procedure Code provides that a request is filed at least three days before the date set for the hearing or before the commencement of the main judgment, thus giving the court the opportunity to assess how it should be proceed further in the adjudication of the case.

The abbreviated trial, is a special procedure in which the preliminary hearing judge without entering into the main trial phase, delivers a judgment on the basis of the indictment filed by the prosecutor and the material contained in the prosecutor's file. This judgment avoids the stage of judicial investigation.

\section{The Procedural Time of Submitting the Application}

An important requirement for an abbreviated trial is the request submitted by the defendant or by his lawyer in court, before the judicial review is declared open. When the main judgment has commenced with ordinary procedure, it can not be continued with an abbreviated trial.

\footnotetext{
${ }^{1}$ Article 93, of the Code of Criminal Procedure of the Republic of Albania, Separation of cases: 1 . The division of cases is decided, even mainly, only when the factual evidence is not damaged in the cases provided for in this article.
} 
In a judgment with some defendants, it can not be processed for some with the special proceedings and for others with ordinary proceedings. Only in the case under Article 93 of the Criminal Procedure Code ${ }^{1}$, is decided the separation of the case, and may allow an abbreviated judgment to defendants who have requested such procedure and issue aside for the other defendants whom seek ordinary judgment. It is conceptually wrong when accelerated procedure applied only as a benefit to the defendant.

This alternative judgment, in contrast to an ordinary judgment, it lacks the stage of taking evidence and the requirements related to their invalidity. If the parties have allegations regarding the absolute or relative invalidity of the evidence and require the ascertainment or declaration of invalidity, the court must revoke the decision foran abbreviated trial and order the continuation of the ordinary trial. When the lawforesees that the court ${ }^{2}$ decides to proceed with anabbreviated trial in the state of the acts, means that the court has the obligation to consider the acts in advance, before deciding to accept the claim, and if it ascertains in advance that their invalidity affects the taking of a fair decision, it should not accept from the beginning the request for an abbreviated trial.

\section{Court Dispositions and Cases of Judicial Practice}

Whenfor a defendant has more than one charge, may be allowed an abbreviated trial for one or more of them, when required by the defendant, on the condition that the case has to be divided and judged separately, without prejudice to proceedings on the other matters, as provided by Article 93 of the Criminal Procedure Code ${ }^{3}$.

\section{Case 1}

The Tirana Court of Appeal, has ruled that the decision of the First Instance Court, has been taken in contravention with the procedural rules established for an abbreviated trial, the Criminal College of the Court of Appeal concludes that the decision No. 130 dated 06.02.2012 of the Tirana District Court is not grounded in the law and as such it must be overturned and the case should be sent for retrial in that court with another trial panel${ }^{4}$.

Concretely:

The Tirana Court of Appeal states that: Decision No. 130, dated 06.02.2012 of the Tirana District Court was taken in the wrong application of the procedural law. From the acts in the trial file, namely the minutes of the trial, the act which reflects the court's activity at the court hearings, result that: Judicial hearings have been postponed for procedural reasons and specifically for non-appearance and lack of knowledge of the parties to the judgment.

The defendant, was assigned aprimarily appointed lawyer, by proceeding with ordinary judgment, where the parties submitted their allegations and the evidence to be considered. At the hearing with an intermediatedecision the court based on Article 357/1 of the Criminal Procedure Code ${ }^{5}$ has allowed the taking of evidence for review and subsequently postponed the hearing. At the next session, which was conducted in the absence of the defendant but in the presence of the prosecutor, apart from the lawyer appointed primarily by the court, has also been presented the lawyer with a special proxy for defending the defendant in her absence.

By an intermediate decision, the court has replaced the primarily appointed lawyer withthe lawyer assigned by the defendant. The lawyer assigned by the defendant has requested to proceed with an abbreviated trial and the court has accepted the request. It results that from the date of the 23.05.2011, the day that the first court session was held until 06.02.2012 the day that was announced the decision by the first instance court have passed in total about 8 (eight) months and have been developed in total 15 (fifteen) court hearings.

\footnotetext{
1 lbed.

2lbed.

${ }^{3}$ See Decision No. 130, dated 06.02.2012, of the Tirana District Court

${ }^{4}$ Article 357 of the Code of Criminal Procedure, "Provisional Court Provisions" 1. The Court, after hearing the parties, issues a decision on the taking of evidence.

${ }^{5}$ See Article 403 of the Code of Criminal Procedure, paragraph 1 "The defendant or the special representative may request that the case be concluded until a judicial hearing has commenced."
} 
In addition, the Criminal College of theTirana appeal court conclude that the administration of the judicial process at the court hearings carried out by the First Instance Court has violated the procedural rules. ${ }^{1}$ In this case, it results that the Tirana District Court after legitimizing the parties and their representatives has started the ordinary court hearing. At the eighth session, after replacing the primarily appointed lawyer, has proceeded with an abbreviated trial. In the interpretation of Article 403 of the Criminal Procedure Code but also in implementation of the unifying decision of the Supreme Court No. 2 dated 29.01.2003², Criminal College of Tirana Court of Appeal considers that when the judicial examination has begun with ordinary judgment can not proceed further with an abbreviated trial. In the interpretation of Articles 403, 404, 405 and 406 of the Criminal Procedure Code, the Criminal College of the Appeal Court considers that these provisions, the legislator has no intention ofmixing the special proceedings (the abbreviated trial) with the ordinary judgment.In the application and interpretation of Articles 403-406 of the Criminal Procedure Code, the request for anabbreviated trialmay take place until the judicial hearing has not yet begun and can not be restated when it has begun. The decision of the First Instance Court was taken in contravention with the criminal procedural rules for an abbreviated trial.

\section{Case 2}

Librazhd, Judicial District Court with Decision No. 64 , dated $1.10 .2006^{3}$ has found the defendant guilty for the criminal offenses of intentional murder against two persons committed in cooperation and illegal possession of weapons, also making use of a counterfeit passport. The Durrës Court of Appeal, by decision no. 267 dated 19.6.20074 has decided to leave in force the decision no. 64 of 1 October 2006 of the Librazhd Judicial District Court, whereas the Criminal College of the High Court, in the Counseling Chamber, by decision no. 211 of 9 April 2009, ${ }^{5}$ has decided not to accept the recourse. The petitioner claim a violation of the right to a fair legal process because: ... the decision to overturn the request an abbreviated trial has violated the applicant's right to benefit from the reduction of the sentence according to the Criminal Procedure Code. The decision to overturn the request for an abbreviated trial it is unjustified, failing to fulfill the obligation foreseen in Article 142/1 of the Constitution and Article 112/1 of the Criminal Procedure Code.

On the allegation for the violation of the right to access to a court (access right), the Constitutional Court finds that this claim, in essence, deals with the ground of the decision to overturn the request foran abbreviated trial by the court of first instance as well as the denial by the Durrës Court of Appeal of the right to appeal and access to this court to control the decision of the first instance court.

\section{The issue to be solved is:}

The omission from the judicial jurisdiction of the first instance court decision to refusethe abbreviated trial violates the applicant's right of access to a second instancejudgment? In this regard, the Constitutional Court notes that, according to articles 407/3 and 422 of the Criminal Procedure Code, the defendant has the right to appeal decisions of the first instance court.

This right of appeal extends both to the guilty verdict as well as to the punishment given by this court. This means that, in relation to the sentence, the defendant may appeal the measure of punishment given from the point of view of respecting the principle of proportionality. This principle is also violated if the criteria for an abbreviated trial are met, with the consequence of a reduction in one third of the sentence (Articles 404 and 406/1 of the Criminal Procedure Code).

Consequently, if in the first instance it is continued with the ordinary judgment procedure, the court decision may be appealed for an unlawful punishment, arguing that the refusal of the abbreviated trial is unjustified or incorrect.In this case, the defendant requests that the court of appeals examine the grounds on which the decision of non-acceptance of the abbreviated trial is based, challenging this decision because it has questioned the legality of the punishment given. Consequently, the concrete determination of the punishment is reassessed by the appeal court and if this court finds that it is unjustifiable to reject the abbreviated trial, it should apply a reduced sentence, although the procedure followed was

\footnotetext{
1 Unifying decision of the United Chambers of the Supreme Court, no. 2, dated 29.01.2003.

2 See Decision of the Court of Judicial District Librashd No.64, dated 01.10.2006.

${ }^{3}$ See Decision No. 267, dated 19.06.2007 of the Durrës Court of Appeal.

${ }^{4}$ See the Decision of the Criminal College of the High Court, No.211, dated 09.04.2009

${ }^{5}$ See Constitutional Court decision no. 14, dated 26.3.2012, pg.23 and 24.
} 
not that of the abbreviated trial. Thus the motives of the decision rejecting the abbreviated trial, which affect the legality of the punishment to be given, can not be excluded from the substantive review on appeal.

All this, not with the purpose of recovering the special proceeding but of the appeal, in case of punishment, of reduced punishment. ${ }^{1}$ In the present case, the Constitutional Court determine that the Durrës AppealCourt by its decision No. 267 of 19 June 2007 was its assessment that the disposition regarding the acceptance or not of the request for an abbreviated trial is the attribute of first instance Court. This means that, according to the assessment of the Durrës Court of Appeal, the decision of the court of first instance, regarding the refusal of the request for anabbreviated trial, is not subject to judicial control in the second instance. In the opinion of the Constitutional Court, this means that the lack of control in the second instance of this decision, the refusal, denies access to a second instance judgmentregarding the allegations of noncompliance of the principle of proportionality in determining of punishment. Consequently, the Constitutional Court concludes that this approach of the appellate court has, in itself, violated the applicant's right of access and to appeal to a higher court.

Another issue that is required to be solved is: Can the legal qualification of a criminal offense be changed during an abbreviated trial?

The Constitutional Court has pointed out in its jurisprudence that the institute of changing the legal qualification of a criminal offense during the judgment may be applied by the courts of ordinary jurisdiction during ordinary adjudication only when the requirements set by the Court itself are strictly applied, in particular with regard to guaranteeing the realization of the right of defense of the parties to the judgment to the new formulation of the criminal offense. "The application of Article 375 of the Criminal Procedure Code in this way is a guarantee for the development of a fair legal process by placing the court in its role of giving justice"?

Also, with regard to the institute under consideration, the ECHR ${ }^{3}$ has stated that "the provisions of paragraph 3 of Article 6 sanction the need to give particular attention to the notification "of the charge"to the person concerned. Since the indictment has an important role in the criminal proceeding, article 6, paragraph 3 recognizes the defendant the right to be informed not only of the motive of the charge, that is, the material facts attributed to him and on which the allegations are based, but also, and in detail, with the legal qualification given to these facts"and that "accurate and complete information of the charges against a defendant and the legal qualification of the offense is an important condition for a fair legal process". ${ }^{5}$ This means that defendants should be informed within areasonable time not only with the motives of the charge, that is, with the material facts attributable and on which the allegations are based, but also, and in detail, the legal qualification granted to them facts.

Based on these assessments, the Constitutional Court of Albania notes that the First Instance Court for Serious Crimes, by changing the qualification of the offense, having accepted the defendant's request to proceed with anabbreviated trial, did not respect the requirements defined by the ECHR and Albanian jurisprudence in relation to this institute. Thus, the First Instance Court for Serious Crimes has not given the defendant the opportunity to exercise theright to and effectivedefense against the new criminal offense.

In this respect, the Constitutional Court reiterates its position that while in ordinary judgment it is the exclusive competence of ordinary courts of law to change the legal qualification of a criminal offense, in special judgments, as considered an abbreviated trial, the right must be exercised in accordance with the particulars of this judgment, in particular with the fact that, in order to proceed with this kind of judgment, besides the defendant's request, the decision / approval of the judge is necessarily required. In other words, the judge when is deciding as whether or not to accept the request of the defendant for an abbreviated trial should consider not only the principle of judicial economy, but must decide primarily, in accordance with the principle of effective justice. This means that he, among other things, should also consider the legal qualification

\footnotetext{
1 See decision No. 51, dated 30.07.1999 of the Constitutional Court. Article 375 of the Code of Criminal Procedure reads: "With a final decision the court may give a fact different from the one made by the prosecutor or the aggrieved party, easier or more severe, provided that the offense is in its competence.

${ }^{2}$ European Court of Human Rights.

${ }^{3}$ See decision No. 14, dated 26.03.2012 of the Constitutional Court.

${ }^{4}$ See decision No. 51, dated 30.07.1999 of the Constitutional Court.

${ }_{5}$ Vargas and Peñaloza (2004) address the economic and social costs of not complying with judicial decisions, making estimates with Spanish data.
} 
of the criminal offense established by the prosecutor. Consequently, if there is any doubt about this qualification, this element suffices for a judge to overturn the defendant's request to proceed with a special judgment and to continue the judgment by the ordinary procedure, thus respecting all the principles of a fair process, such as contradictory, the right to protection, etc.

\section{Conclusions:}

1. In an abbreviated trial, as a special proceedings, is essential the acceptance of the acts on the basis of the indictment filed by the prosecutor and the material contained in the prosecutor's file. This special proceedings avoids the stage of judicial investigation.

2. A request for an abbreviated trial, can be made until thejudicial review has not yet started and can no longer be presented when it has begun. When the main judgment has commenced with ordinary judgment, it can not be continued with an abbreviated trial.

3. The Judge when deciding, whether or not the request of the defendant for an abbreviated trial must be accepted, consider not only by the principle of judicial economy, but must, in principle, decide, in accordance with the principle of effective justice. This means that he, among other things, should also consider the legal qualification of the criminal offense established by the prosecutor. Consequently, if there is any doubt about this qualification, this element suffices for a judge to overturn the defendant's request to proceed with a special proceeding and to continue the trialwith an ordinary procedure, thus respecting all the principles of a fair legal process, such as the contradictory, the right to protection, etc.

4. When the ordinary jurisdiction court proceed with an abbreviated trial, a proceeding in which, the court can only takes into consideration the prosecutor's file, there is no possibility of exercising the effective right of defense by the defendant, so changing the legal qualification of a criminal offense by the court is contrary to the purpose of this judgment.

5. At a judgment with some defendants, can not be processed some with a special proceeding and the others with ordinary proceeding. Only when a case is split under Article 93 of the Criminal Procedure Code, an abbreviated trial, may be allowed for the defendants who have requested such a judgment and the case is separated for the other defendants who seek ordinary trial.

6. The ECHR has reviewed the abbreviated trial institute in order to guarantee the defendant's right to defense. She emphasized that "the right to be informed of the nature and motives of the charge should be considered in the view of the defendant's right to prepare his defense". This means that defendants should be informed within a reasonable timenot only with the motives of the charge, namely with the material facts attributable and on which the allegations are based, but also, and in detail, with the legal qualification granted to this facts. This is an important condition for ta fair legal process.

\section{References}

[1] Constitution of the Republic of Albania: amended by laws no. 9675/2007; no. 9904/2008; no. 88/2012 and No.137 / 2015 / RS. Assembly. Tirana: The Center for Official Publications, 2016.ISBN 978-9928-01-060-5

[2] Criminal Procedure Code of the Republic of Albania, Tirana 2014, publication of the Official Publishing Center, ISBN 978-9928-01-042-1

[3] Commentary of the Penal Criminal Procedure Code, Halim Isalami, ArtanHoxha and Ilir Panda, Tirana 2013.

[4] Criminal Code of the Republic of Albania

[5] European Convention on Human Rights and Fundamental Freedoms, ratified by Law No. 8137, dated 31.7.1996 "On the ratification of the European Convention for the Protection of Human Rights and Fundamental Freedoms"

[6] Decision No. 130, dated 06.02.2012 of the Tirana District Court

[7] Unification of United Colleges of the Supreme Court, no. 2, dated 29.01.2003.

[8] Decision No.368, dated 14.04.2004, of the Tirana District Court

[9] Decision No.42, dated 21.01.20105 of the Criminal College of the High Court

[10] International Covenant on Civil and Political Rights, ratified by Law No. 7510, dated 08.08.1991.

[11] Decision of the Court of Judicial District Librashd Nr.64, dated 01.10.2006.

[12] Decision No. 267, dated 19.06.2007 of the Durrës Court of Appeal.

[13] Decision of the Criminal College of the High Court, No.211, dated 09.04.2009

[14] Constitutional Court Decision No. 14, dated 26.3.2012, para.23 and 24. 
[15] Uniform Decision of United Colleges of High Court no. 2, dated 29.1.2003

[16] Constitutional Court Decision No. 10, dated 2.4.2009

[17] Decision of the Constitutional Court No. 19, dated 19.7.2005

[18] Decision no. 4, dated 28 February 2006 of the Constitutional Court

[19] Decision of the Constitutional Court no. 211, dated 9.4.2009

[20] Decision no. 14, dated 26.3.2012 of the Constitutional Court

[21] ECHR Decisions in Hermi v. Italy, no. 18114/02, §§ 27-28 and in the case of Hany v. Italy, no. 17543/05.

[22] ECHR judgment in the case of Kwiatkoxska v. Italy, no. 52868/99.

[23] ECJ decision in the case of Scoppola v. Italy, claim no. 10249/03).

[24] ECJ decision in the case of Scoppola v. Italy, claim no. 10249/03)

[25] https://studioligjore.ëordpress.com/2012/02/20/gjykimi-i-shkurtuar-sipas-interpretimeve-te-bera-nga-gjykata-elarte-dhe-ajo-kushtetuese/\#_ftn1

[26] Decision No.378 / 1997 of the Italian Constitutional Court

[27] Decision No.313 / 1990 of the Constitutional Court of Italy

[28] Decision no. 23/1992 of the Italian Constitutional Court

[29] Decision no. 44711, dated 27 October-18 November 2004, of the Italian Cassation Court, § 5.1; § 5.2.

[30] Decision No. 50, dated 30.07.1999 of the Constitutional Court

[31] ECtHR ruling in Pélissier and Sassi v. France, no. 25444/94,

[32] ECHR Decision in Drassich v. Italy, claim no. 25575/04.

[33] Constitutional Court Decision No. 10, dated 2.4.2009

[34] Constitutional Court Decision No. 19, dated 19.7.2005

[35] Decision no. 4, dated 28 February 2006 of the Constitutional Court

[36] Decision no. 5, dated 02.03.2010 of the Constitutional Court

[37] Decision no. 14, dated 14.04.2010 of the Constitutional Court

[38] Decisions no. 4, dated 23.02.2011; no. 14, dated 3.6.2009 and no. 7 dated 11.03 .2008 of the Constitutional Court

[39] Unifying decision of the Supreme Court no. 2/2003

[40] Decision no. 5, dated 02.03.2011 of the Constitutional Court

[41] ECtHR, Stoichkov v. Bulgaria, 24 March $2005 \$ 66$

[42] Decision no. 44711, dated 27 October-18 November 2004, of the Italian Cassation Court, $\S 5.1 ; \S 5.2$.

[43] Decision no. 23, dated 17.05.2011 and no. 106, dated 01.08.2001 of the Constitutional Court 